\title{
Community's Participation: A strategic approach in revitalizing heritage streets
}

\author{
Rodzyah Mohd Yunus, Zalina Samadi, Dasimah Omar \\ Faculty of Architecture, Planning and Surveying, \\ Universiti Teknologi MARA, Shah Alam, 40450, Selangor, Malaysia \\ rodzyah99@yahoo.com.
}

\begin{abstract}
City dynamic often dominates by street shoppers, pedestrian and vehicular traffics. The dynamic ambiance in heritage streets is not an impromptu scenario but a value innovation from the street's committee. The first objective of this research is to identify the street's committee's strategy, the second is to classify their strategies and the third is to compare and find the best strategies. The evaluation on strategies is analyzed from the semi-structured interview and content analysis. Finally, a consensus of a strategy in the making of successful heritage street as an innovative marketplace is produced in capitalizing heritage tourism endeavor.
\end{abstract}

Keywords: Revitalization strategy; great heritage street; heritage street committee, community's participation

eISSN 2514-7528 @ 2018. The Authors. Published for AMER ABRA cE-Bs by e-International Publishing House, Ltd., UK. This is an open-access article under the CC BY-NC-ND license (http://creativecommons.org/licenses/by$n c-n d / 4.0 /$ ). Peer-review under responsibility of AMER (Association of Malaysian Environment-Behaviour Researchers), ABRA (Association of Behavioural Researchers on Asians) and cE-Bs (Centre for EnvironmentBehaviour Studies), Faculty of Architecture, Planning \& Surveying, Universiti Teknologi MARA, Malaysia.

DOI: https://doi.org/10.21834/jabs.v3i10.301 


\subsection{Introduction}

Street shoppers, pedestrian and vehicular traffics in heritage streets may have been a catalyst for city dynamic which provides continuous movement within the outdoor of street. The quality of outdoor space in between heritage streets like Oxford Street in London, Queen Street in Oxford, Berlin Street in Germany, Orchard Street in Singapore and Via Monte Napoleone in Milan provide lively ambience. The streets offer a variety of forms, fashion, pattern, design, graffiti scene, brand and colors of products sale along the street. The heritage facades which are rich in art and craft decorations of its heritage characteristic incorporate graffiti, technology within the limit of each window displays and showcases. The indoor shopping acts as a permanent outlet which supports the outdoor activities along those streets. This ambiance of a lively heritage street is not an impromptu situation but it is a value innovation from a heritage street's committee.

Heritage street committee is a heritage shop owners union. In other heritage cities, they unite due to their high awareness on their heritage property's value publication. They are fully aware of the economic, social and environmental value of their heritage property especially attracting tourism (Britt, K.M. 2009). This stance is supported by Laing, J. (2011) that considers those as an important component in sustaining the marketing of cultural and heritage tourism. The heritage committee members are actively enhancing their property's visual richness and façade attractiveness. This new sense of space with views and vistas of the on-street shopping activities consider as blue ocean strategy.

This innovative approach of heritage streets' market place inspires an idea of research conduct to take place at Jalan Hang Jebat, Melaka, Malaysia. The aim is to investigate a set of strategy for making a great heritage street. The first objective of this research is to identify the strategy from the Jalan Hang Jebat's Heritage Committee. They are the local community who lives and works in the heritage shop houses. The second objective is to classify their strategy. The third objective is to compare strategies with other heritage streets' communities to find the best strategy. In this study, an evaluation on differences and similarities as analyzed from the community's participation in the Focus Interview (FI). Finally, this research results a new consensus of a heritage street's Revitalization Strategy (RS). The RS is a useful design guide for creating a great heritage street as an innovative marketplace in capitalizing heritage tourism endeavor.

\subsection{Literature Review}

\subsection{Community's Participation}

The earlier research discussion with regards to the quality of 'space in between heritage buildings' has highlighted the space appropriateness for 'urban outdoor living'. The space supposed is designated for 'urban recreation activities' rather than left as 'unintended' and 'no man's land' (Samadi, Z. and Hasbullah, M.N., 2008). Evans (2009) promotes creative spaces in revitalizing urban area by all means of design principles to reduce unintended and crime-prone area. Likewise, in a study on sustainable home environment, community's 
participation plays a vital role in shaping their future environment with specific cultural values (Masri et al, 2014). Edwards, Griffin \& Hayllar (2008), identified weakness on the lack of integration of spaces among practitioners, researchers and policy makers in which leads to urban negative spaces. This is one of the heritage threats of a livable heritage city which caused under-utilized space in the urban area. In order to resolve these urban problems, a strategic revitalization action is needed for implementation. Many heritage city authorities use to nominate a developer to perform this urban implementation. This approach caused paradoxical juxtaposition between the developer and shop owners. Some of the appointed developers play the God's role and does what they feel like to do without respect and proper justification. Less consideration is provided to the end users who lived for more than two or three generations within the space.

\subsection{Great Heritage Street}

A high social concern in designing urban heritage's outdoor space with positive aura has inspired a heritage committee to act in the heritage street of Melaka. Initially, there was no formal committee. The only alive committee was a family-tied union, which caters local issues and update within shop houses neighborhood. The heritage street's committee in early 1990's was formerly lead by Datuk Wira Gan Boon Leong. He aimed to boost the tourism industry in the UNESCO World Heritage Site, in Melaka. This aspiration of great heritage street even through is not clearly stated, but his idea also shared with the city authority; known as Majlis Bandaraya Melaka Bersejarah (MBMB) and the Melaka World Heritage Sendirian Berhad. The authorities have an on-line access for collecting public feedback. Their aim is finding the most strategic approach to revitalize the dying heritage streets. The Core Zone of the Heritage City of the Straits of Malacca shall continue living. In this research, the great heritage street refers to a street that demonstrates the best physical and spiritual quality. Both qualities provide visual stimulation to magnify physical and spiritual attraction. The visitors may experience a positive aura of vibrancy, youthfulness and freshness.

\subsection{Heritage street committee}

The Jalan Hang Jebat committee members are constituted from shop owners and operator unity. They have high interest and actively enhancing their property's visual richness and façade attractiveness. The fact of the historical façade is not hidden behind the commercialization, but the antiquity is enhances through various ways depending on the owners creativity. The direct relationship between pedestrian movements and on-street activity to revitalize a positive aura within a heritage outdoor space is visible, but further studies on heritage street's therapeutic attributes with pedestrian prove that indulging in creative activities such as outdoor street shopping often decreases solemnity and increases livability.

\subsection{Street's shopping}

The indoor and on-street shopping during "Pasar Malam" has reflected the outstanding universal value of Melaka is on her 'multi-culturalism' quality which rarely found to the world. The cultural heritage is demonstrated through the continuous trading lifestyle as inspired form 
previous port city activity. They are the sub-cultures from Asian such as India, China, Malay and other continent from Europe. There are mainly three most outstanding universal values as demonstrated the living testimony of tangible and intangible heritage, the multi-trading town as forged from exchanges of culture and the melting pot of multicultural architecture and township. The façade reflects the architectural style of its built heritage is demonstrated in the historical shop houses. The similar value and built heritage of early shop houses can also be found in Melaka and George Town, Penang. The similarity of image and identity shop houses are due to the identical social influences of the heritage cities of the Straits of Malacca which spice up with architecture from the British Colonial, European, Asian and multi-ethnic influences.

\subsection{Methodology}

The form of data collected in this research is in the form of focus interview. The selection of heritage streets is justified through the hierarchy of the street which is located within the Core Zone. Jalan Hang Jebat is accepted by public as one of the most vibrant streets with high security and surveillance. This street also has the highest visual attractiveness that reflects its richness in heritage character. Therefore, this juxtaposition has elevated this street with added value as a unique identity: 'vibrant but secure street'. The uniqueness of this street is the combination of vibrant activities and high surveillance. In addition to that, the street has weekly night market called "Pasar Malam". This event takes place every Friday to Sunday nights. During this event, the street is closed from vehicular traffic, and the street becomes heaven for street shoppers. No doubt, this street has its own bold value on top of the outstanding universal value as established in UNESCO World Heritage Sites in 2008.

\subsection{The community's participation}

This research was conducted in between January 2013 to March 2013 with obtrusive measures. In terms of research participation, semi-structured interview does involve endusers direct involvement. The respondents are the shop owners or shop operators who live, play, work and operating business along Jalan Hang Jebat, Melaka. They are the local community who owned the heritage shop houses from the previous generation. Their reflection in the semi-structured interview is purposeful for recording their revitalization strategy, routine behavior and decision making with regards to the future of heritage shop houses. They are the end-users in the real phenomenon on the livable street. The application of log sheets is the means for recording the conversation between researcher and the respondents for transcription process prior to coding and classification in the analysis system.

\subsection{The preliminary measures}

The focused interview on-street sessions take place within the shop owners/operators shop lot to avoid disturbance of their routine. There were no appointments done prior to conduct the interview. This impromptu situation is initially planned to avoid any unreal situation. The interview is the properly plan questionnaire for an immediate response from interviewees in reflecting their experience based real phenomenon operating business in the heritage street. 
The duration of the interview took the first half an hour to maximize the opening session in business operation. The shop owners' or operators' routine normally begins as early as possible between seven thirty and eight o'clock in the morning. The activity begins with water cleansing on shops' five foot walkway and watering plants at the shop fronts of their premises. This activity is part of their daily routine to maintain cleanliness. After cleaning session, they perform their morning pray to for encouraging fortune and prosperity in their business activities. Some of them lit up their highly scented incense stick or joss stick in front of their shop lots. This burning activity creates overwhelming smell in which associates them with Buddhism.

\subsection{The focus interview (FI)}

The interview session takes about half to forty minutes time. This paper shares the step by step in conducting the interview. The first step was Pre-Interview in which a set of semistructured questionnaires were designed and tested. This step is to verify question from any error. A study on the interviewee in terms of ethnical background, ethics, general principle, Feng Shui and lifestyle of business are carefully understood avoiding misunderstanding and lack of cooperation during interview. This is part of the preconceive measures prior to the FI. The second step is the on-site interview session. The interviewer must introduce him/herself and share the interview intention. The first impression is very important to gain their confident on the interviewer. Then start knowing each other, relax and enjoy the session. After the icebreaking session, then only the main interview begins. In order to maintain the session, the researcher has to be flexible in terms of the sequence of questioning.

The interviewer may start to tick the preferred answers while encouraging them to continue communicating. The interviewer shall conduct this session with full of attention, enjoy any jigsaw puzzle and just follow the flow. The interviews are ended with thankful words from the interviewer to the interviewees for their time and information. At this point of time, the researcher may hand-over a token to interviewees to elicit his/her sense of appreciation. The third step in this $\mathrm{Fl}$ is post interview. The interviewer i.e. the researcher gathers all data as collected from the interview, interpret, classify and coding the responses accordingly. Finally, the analysis of the result is deduced and synthesized.

The findings of this research, only share the result that relates to the revitalization strategy in the making of the great heritage street. In this paper, the demographic profile of the total population indicates that the Malaysian Chinese with Baba Nyonya inheritance is the majority ethnic owning/operating the heritage shop owners at Jalan Hang Jebat, Melaka.

They welcomed the researcher as their first customer due to proper time selection. This is part of the 'homework' which was earlier done to get the most suitable time for interview session. Their direct participations are observed through gesture and speaking intonation. The Focus Interview (FI) answer also can be confirmed in their non-verbal behavior during the session. The following Figure 1 presents the three main steps in conducting the interview with shop owners 

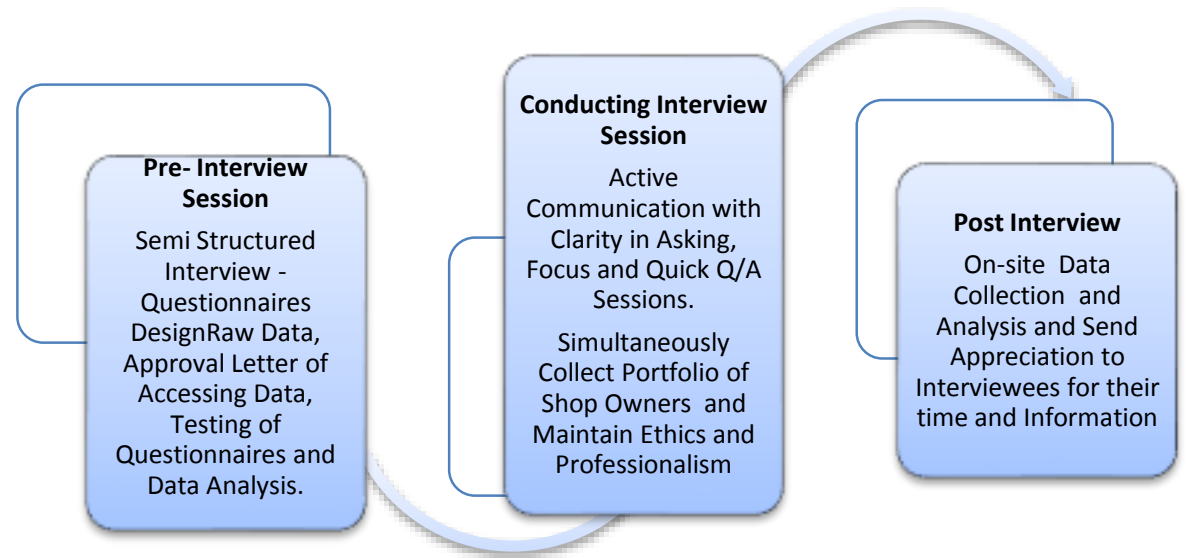

Fig.1. Three main steps in conducting community's participation

\subsection{The questionnaires design}

This research employed obtrusive-data collection with on-street interviews were marked on interview log sheet for recording shop owners feedback. This on site data log sheet was counter checked again during the process of analysis for validating the result. The data log sheets were printed in A4-sized form as prepared for public participation survey. During the interview session, the log sheet was not physically directed to interviewees. It remains as a personal reference to the researcher as long as she/he can post a question as clear as possible. After each session, the log sheet is completed by researcher before another interview takes place. The following section shares the result of this study.

\subsection{Results and Discussions}

Based from the earlier research on pedestrian pattern and on-street activity at Jalan Hang Jebat, Melaka (Samadi, Z. \& Mohd Yunus, R., 2012), the most preferred activity is an indoor shopping, which is lineage along the heritage shop houses. The second preferred activity is the indoor and outdoor shopping and the third preferred activity is the on-street shopping. Thus it is vital to highlight these activities in relation to the revitalization strategy. The research categorized these strategies into major and minor revitalization strategy (refer to Table 1 and 2)

\subsection{The major revitalization strategy}

In this focus interview regarding major revitalization strategy, the highest percentage is reflected as the majority of fifty three percent of shop owners choose to have their own developer. The rejection of developer's appointment from the Majlis Bandaraya Melaka Bersejarah (MBMB) is clearly reflected through the result in option five. Based on the result, only a minority of four percent from the shop owners had selected this option. In contrast, 
they preferred their own developer and rejected the city authority's developer. The analysis on the provided data with limitation which is based on shop owners views and experience from the total population of one hundred and six [n=106] only.

Table 1. Result of major revitalization strategy

\begin{tabular}{|l|l|c|l|}
\hline [Respondents] & $\begin{array}{l}\text { [Five Options of the Major Revitalization } \\
\text { Strategy]. }\end{array}$ & $\begin{array}{l}\text { [Legend of } \\
\text { Options]. }\end{array}$ & $\begin{array}{l}\text { [Percentage } \\
\text { of Selected } \\
\text { Strategy } \\
\text { [n: 106]. }\end{array}$ \\
\hline $\begin{array}{l}\text { [Shop owners / } \\
\text { Shop operators]. }\end{array}$ & $\begin{array}{l}\text { ["No Future Development And } \\
\text { Live As It Is"]. } \\
\text { ["Heritage } \\
\text { Committees' Developer"]. } \\
\text { ["Melaka World Heritage } \\
\text { Incorporation's Decision"]. } \\
\text { ["Freedom Of Individual Development } \\
\text { Choice"]. }\end{array}$ & 2. & $53(\%)$. \\
["Developer Appointment by MBMB"]. & 4. & $10(\%)$. \\
\hline
\end{tabular}

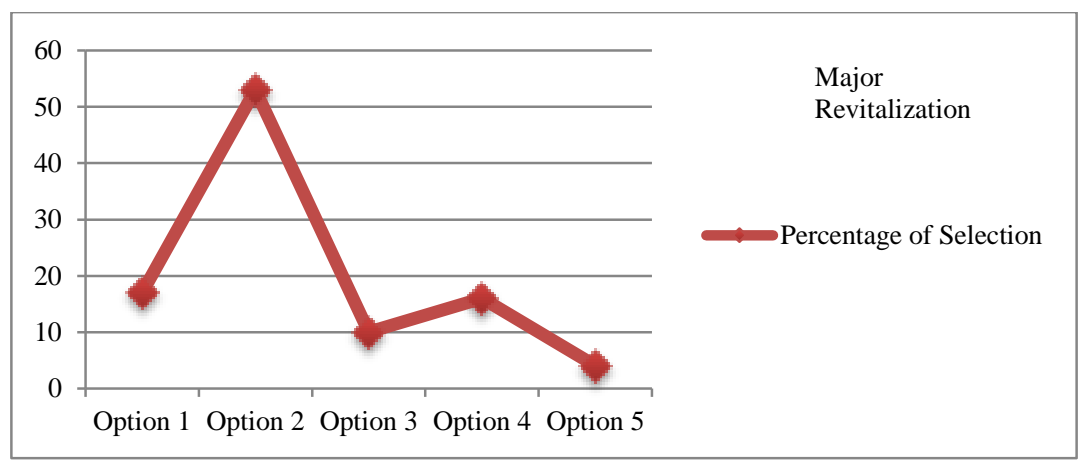

Fig.2. Chart of major revitalization strategy as reflected by heritage shop owners of Jalan Hang Jebat

\subsection{The minor revitalization strategy}

There are five main views as provided to shop owners in Jalan Hang Jebat, Melaka. The following result as shown in Table 2 and Figure 3, in this paper only shares the minor revitalization strategy in which reflects the individual view of the total population of the study street. Thirty one percent from the respondents has chosen eye catching window display. The visually stimulating strategy is to attract street shoppers to stop and buy from their premises. The least selected option is on the themed interior with high permeability and 
accessibility only scores four percent. This decision is reflected from their preference on crowded environment. In their thinking, high density street shoppers around their premises may benefit product marketing and sales. The crowds also reflect vibrancy. As earlier mentioned, the presented data analysis and result in this paper is limited to shop owners' views and experience only. The result is derived from the total population of one hundred and six units of heritage shop houses [ $\mathrm{n}=106]$. (10 Arial)

Table 2. Result of the individual shop lot

\begin{tabular}{|l|l|c|l|}
\hline [Respondents]. & $\begin{array}{l}\text { [Five Options of the Minor Revitalization } \\
\text { Strategy]. }\end{array}$ & $\begin{array}{c}\text { [Legend } \\
\text { of } \\
\text { Options]. }\end{array}$ & $\begin{array}{l}\text { [Percentage of Selected } \\
\text { Strategy } \\
\text { [n: 106]. }\end{array}$ \\
\hline [Shop owners/ & ["Special, Antique and Unique & 1. & $29(\%)$. \\
shop operators]. & Products"]. & 2. & $20(\%)$. \\
& ["Marketable Souvenir"]. & 3. & $18(\%)$. \\
& ["Friendly Behavior"]. & 4. & $31(\%)$. \\
& ["Eye catching. Visually & 5. & $2(\%)$. \\
& stimulating"]. & $100(\%)$. \\
& ["Themed Interior. Permeability and & & \\
& Accessibility"]. & & \\
\hline
\end{tabular}

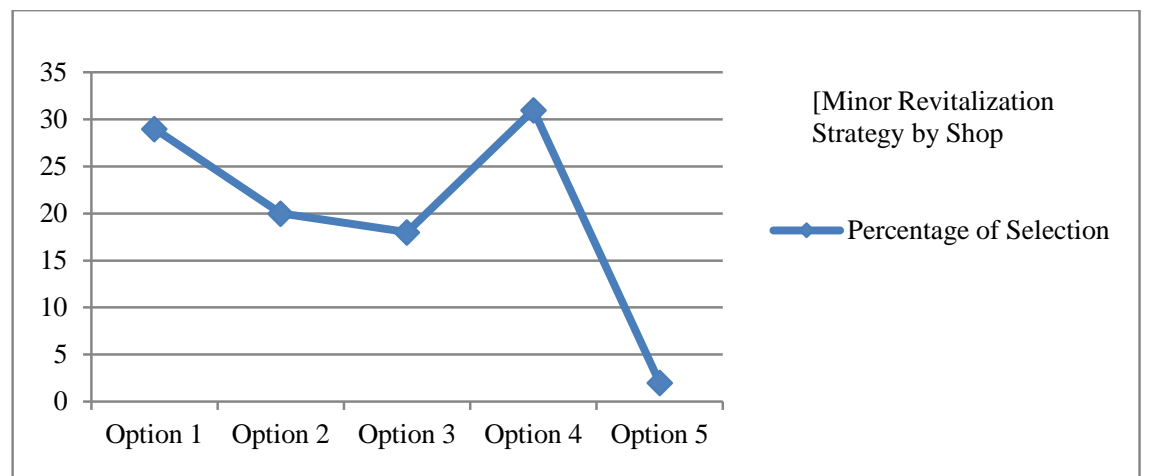

Fig.3. Chart of individual revitalization strategy as reflected by heritage shop owners of Jalan Hang Jebat.

\subsection{Conclusion}

The shop owners committee's active participation of the Jalan Hang Jebat in managing the heritage street provides high impact towards the revitalization effort. Their participation not only limited on ensuring the economic revitalization but also commit safety and surveillance issues. Shop owners are particular in selecting the marketable product. Their choice of product for selling is from authentic, unique and antique items to be displayed and sell in their premises. The themed interior layout gets the least attention (two percent score) except for shop owners with hotel/motel operation. Their decision making can be concluded as prone to cost minimization and profit maximization. Their way of thinking is closely related to the 
principle of maintaining business sustainability. The employed data collection through public participation analysis is encouraging and has improved confidence towards street's public participation and documentation by researcher. By having this study, hopefully it provides a strategic approach in revitalizing any heritage streets.

\section{Acknowledgements}

The author wishes to dedicate special acknowledgement to all shop owners of the Jalan Hang Jebat on their full cooperation during interview sessions as participants and to Majlis Bandaraya Melaka Bersejarah (MBMB) on their officer's kind cooperation during the data collection. Unforgettable acknowledgement dedicated to Universiti Teknologi MARA (UiTM) for funded the research study.

\section{References}

Appleyard, D. (1980). Livable streets: Protected neighborhoods? The ANNALS of the American Academy of Political and Social Science. Retrieved from doi:10.1177/000271628045100111.

Britt, K. M. (2009). Lancaster renaissance: Urban revitalization, heritage tourism, and community archaeology. ProQuest Dissertations and Theses.

Edwards, D., Griffin, T., \& Hayllar, B. (2008). Urban Tourism Research. Annals of Tourism Research, 35(4).

Evans, G. (2009). Creative cities, creative spaces and urban policy. Urban Studies, 46(5-6).

Laing, J. (2011). Sustainable marketing of cultural and heritage tourism. Journal of UNESCO World Heritage Centre. Operational Guidelines for the Implementation of the World Heritage Convention. In Operational Guidelines for the Implementation of the World Heritage Convention (p. 167).

Lamin, A., \& Zaheer, S. (2012). Wall street vs. main street: Firm strategies for defending legitimacy and their impact on different stakeholders. Organization Science. Retrieved from doi:10.1287/orsc.1100.0631.

Masri, M., Yunus, R.M., Ahmad, S.S. (2014). Creating Cultural Innovation: Towards a Holistic Approach in Shaping a Sustainable Future. ASIA Pacific International Conference on Environment-Behavioural Studies (AicE-Bs 2014Berlin) ,Berlin, 24-26 Feb. 2014.

Samadi, Z., \& Hasbullah, M. N. (2008). The enhancement of space in between urban recreation development. Online Refereed Journal of Malysian Publication. Retrieved from http: //www. malaysianpublications.blogsport. com/

Samadi, Z., \& Mohd Yunus, R. et al. (2012). Conflict of image and identity on heritage commercialization. Conference Procedia- Environmental Behaviour, 50, 674-684.

Shamsuddin, S. et al. (2012). Walkable environment in increasing the livability of a city. Conference ProcediaEnvironmental Behaviour.

Shamsuddin, S., Sulaiman, A. B., \& Che Amat, R. (2012). urban landscape factors that influenced the character of George Town, Penang UNESCO World Heritage Site. Conference Procedia- Environmental Behaviour. 